\title{
Chronic inflammation as a determinant of future aging phenotypes
}

\author{
Tasnime N. Akbaraly PhD, Mark Hamer PhD, Jane E. Ferrie PhD, Gordon Lowe DSc, G. David Batty PhD, \\ Gareth Hagger-Johnson PhD, Archana Singh-Manoux PhD, Martin J. Shipley MSc, Mika Kivimäki PhD
}

\begin{abstract}
Background: The importance of chronic inflammation as a determinant of aging phenotypes may have been underestimated in previous studies that used a single measurement of inflammatory markers. We assessed inflammatory markers twice over a 5-year exposure period to examine the association between chronic inflammation and future aging phenotypes in a large population of men and women.
\end{abstract}

Methods: We obtained data for 3044 middleaged adults ( $28.2 \%$ women) who were participating in the Whitehall II study and had no history of stroke, myocardial infarction or cancer at our study's baseline (1997-1999). Interleukin-6 was measured at baseline and 5 years earlier. Cause-specific mortality, chronic disease and functioning were ascertained from hospital data, register linkage and clinical examinations. We used these data to create 4 aging phenotypes at the 10-year follow-up (2007-2009): successful aging (free of major chronic disease and with optimal physical, mental and cognitive functioning), incident fatal or nonfatal cardiovascular disease, death from noncardiovascular causes and normal aging (all other participants).
Results: Of the 3044 participants, 721 (23.7\%) met the criteria for successful aging at the 10year follow-up, $321(10.6 \%)$ had cardiovascular disease events, 147 (4.8\%) died from noncardiovascular causes, and the remaining $1855(60.9 \%)$ were included in the normal aging phenotype. After adjustment for potential confounders, having a high interleukin-6 level (> $2.0 \mathrm{ng} / \mathrm{L}$ ) twice over the 5year exposure period nearly halved the odds of successful aging at the 10-year follow-up (odds ratio [OR] 0.53, 95\% confidence interval $[\mathrm{Cl}]$ 0.38-0.74) and increased the risk of future cardiovascular events (OR 1.64, 95\% Cl 1.15-2.33) and noncardiovascular death (OR 2.43, 95\% Cl 1.58-3.80).

Interpretation: Chronic inflammation, as ascertained by repeat measurements, was associated with a range of unhealthy aging phenotypes and a decreased likelihood of successful aging. Our results suggest that assessing longterm chronic inflammation by repeat measurement of interleukin- 6 has the potential to guide clinical practice.
$\mathrm{C}$ hronic inflammation has been implicated in the pathogenesis of age-related conditions, ${ }^{1}$ such as type 2 diabetes, ${ }^{2,3}$ cardiovascular disease, ${ }^{4}$ cognitive impairment ${ }^{5}$ and brain atrophy. ${ }^{6}$ Chronic inflammation may result from or be a cause of age-related disease processes (illustrated in Appendix 1, available at www.cmaj.ca/lookup/suppl/doi:10.1503 /cmaj.122072/-/DC1). For example, obesity increases inflammation, and chronic inflammation, in turn, contributes to the development of type 2 diabetes by inducing insulin resistance, ${ }^{7,8}$ and to coronary artery disease by promoting atherogenesis. ${ }^{9}$ Thus, raised levels of inflammation appear to be implicated in various pathological processes leading to diseases in older age.

Of the various markers of systemic inflammation, interleukin-6 is particularly relevant to aging outcomes. There is increasing evidence that interleukin-6 is the pro-inflammatory cytokine that "drives" downstream inflammatory markers, such as C-reactive protein and fibrinogen. ${ }^{10,11}$ Interleukin-6, in contrast to C-reactive protein and fibrinogen, is also likely to play a causal role in aging owing to its direct effects on the brain and skeletal muscles. ${ }^{12,13}$ In addition, results of Mendelian randomization studies of interleukin- 6 and studies of antagonists are consistent with a causal role for interleukin-6 in relation to coronary artery disease, again in contrast to C-reactive protein and fibrinogen. ${ }^{14}$

However, current understanding of the link between chronic inflammation and aging phenotypes is hampered by the methodologic limitations of many existing studies. Most studies reported an assessment of inflammation based on a single measurement, precluding a distinction between the short-term (acute) and longer-term
Competing interests: None declared.

This article has been peer reviewed.

Correspondence to: Tasnime N. Akbaraly, tasnime.akbaraly@inserm.fr

CMAJ 2013. DOI:10.1503 /cmaj.122072 
(chronic) impact of the inflammatory process on disease outcomes. ${ }^{7}$ We conducted a study using 2 measurements of interleukin- 6 obtained about 5 years apart to examine the association between chronic inflammation and aging phenotypes assessed 10 years later in a large population of men and women. Because inflammation characterizes a wide range of pathological processes, we considered several aging phenotypes, including cardiovascular disease (fatal and nonfatal), death from noncardiovascular causes and successful aging (optimal functioning across different physical, mental and cognitive domains).

\section{Methods}

\section{Study population}

We selected participants from the Whitehall II study cohort, established in 1985 among 10308 British civil servants (67\% men). ${ }^{15}$ In brief, all civil servants aged 35-55 years in 20 government departments based in London, UK, were

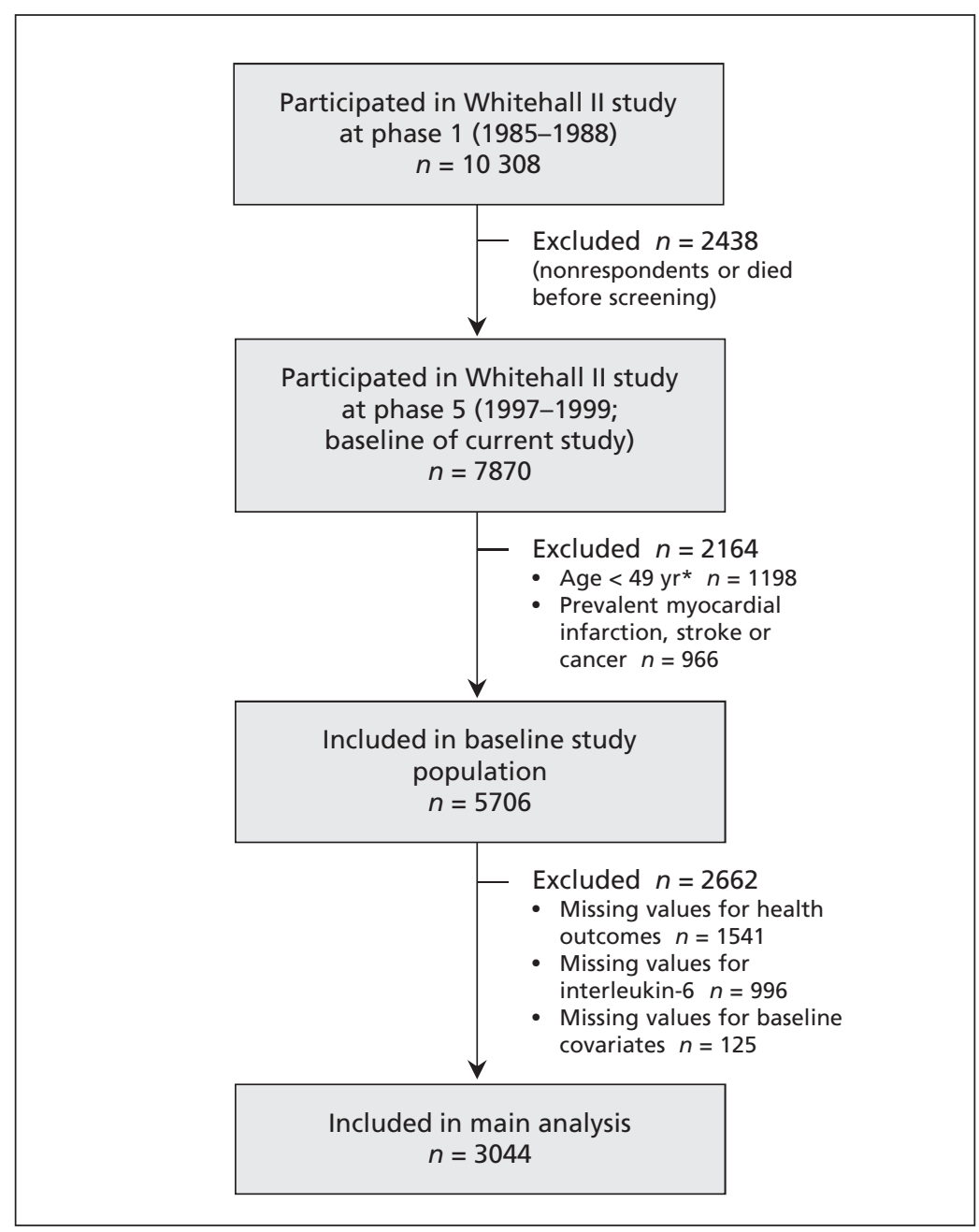

Figure 1: Selection of participants for the current analyses from the Whitehall II study cohort. *Age cutoff chosen to allow follow-up beyond age 60 for surviving participants. invited to participate in the Whitehall II study; $73 \%$ agreed. The study consists of a nurseadministered clinical examination about every 5 years (1985-1988, 1991-1993, 1997-1999, 2002-2004 and 2007-2009). It was approved by the University College London Ethics Committee, and all participants gave written consent.

To allow follow-up beyond age 60 , we included participants who were 49 years or older in 1997-1999 (the baseline for our study). We restricted the study population to the 3044 participants who had no history of stroke, myocardial infarction or cancer at baseline and for whom complete data were available on aging phenotypes at 10-year follow-up (2007-2009), inflammatory markers at baseline and 5 years before baseline (1991-1993), and main covariates at baseline. A flow chart depicting the selection of participants is shown in Figure 1.

\section{Assessment of inflammatory markers}

Interleukin-6, a marker of systemic inflammation, was measured with use of a high-sensitivity enzyme-linked immunosorbent assay (R\&D Systems). ${ }^{16}$ At both the 1991-1993 and 1997-1999 clinical examinations, blood samples were collected between 8 am and $1 \mathrm{pm}$, stored at $-80^{\circ} \mathrm{C}$ and were not thawed or refrozen during storage. Stored serum samples from both phases were analyzed in the same laboratory. Interleukin-6 values below the detection limit $(0.08 \mathrm{ng} / \mathrm{L})$ were assigned a value equal to half the detection limit. Coefficients of variation were $7.5 \%$. The reliability of values across follow-up examinations, assessed with Spearman correlation coefficients, was 0.46 .

C-reactive protein was also measured, with use of an immunonephelometric assay (BN ProSpec nephelometer, Dade Behring). ${ }^{16}$

\section{Baseline covariates}

We obtained sociodemographic data on the participants' sex, age and socioeconomic status (a 3-level measure of low, intermediate or high status based on civil service employment $\operatorname{grade}^{15}$ ). Health behaviours considered in the analyses were smoking status (never, former or current) and physical activity (inactive, moderately active or active) assessed by 20 questionnaire items on frequency and duration of participation in different activities, as detailed elsewhere. ${ }^{17}$ Participants' health status included use of antiinflammatory medication and possible cases of acute inflammation. Use of anti-inflammatory medication was determined from details provided by participants regarding their medication use (generic name, brand name or both). Possible cases of acute inflammation and immune 
activation due to current illness were defined as having a C-reactive protein level greater than $10 \mathrm{mg} / \mathrm{L}$.

\section{Outcome measures}

Four aging phenotypes at the 10-year follow-up were considered: successful aging (free of major chronic disease and with optimal physical, mental and cognitive functioning); fatal or nonfatal (clinically verified coronary artery disease, including myocardial infarction, definite angina and self-reported stroke) cardiovascular disease events; death from noncardiovascular causes; and normal aging (all participants not included in the other phenotypes). ${ }^{17} \mathrm{We}$ ascertained these health outcomes using data from 2 follow-up screenings (2002-2004 and 2007-2009) plus records from national health registers. Further information on the categorization of aging phenotypes is provided in Appendix 2 (available at www.cmaj.ca /lookup/suppl/doi:10.1503/cmaj.122072/-/DC1).

\section{Statistical analysis}

We grouped the interleukin-6 levels measured 5 years before baseline and at baseline into 3 categories: ${ }^{18}$ low ( $\left.\leq 1.0 \mathrm{ng} / \mathrm{L}, n=756\right)$, intermediate (1.1-2.0 ng/L, $n=1456)$ and high $(>2.0 \mathrm{ng} / \mathrm{L}$, $n=832$ ). There are currently no clinical thresh-

Table 1: Baseline characteristics of participants grouped according to aging phenotype at the 10 -year follow-up

\begin{tabular}{|c|c|c|c|c|c|c|}
\hline \multirow[b]{2}{*}{ Characteristic } & \multicolumn{5}{|c|}{ Outcome; no. (\%) or mean \pm SD at baseline } & \multirow[b]{2}{*}{$p$ valuet } \\
\hline & $\begin{array}{c}\text { All } \\
n=3044\end{array}$ & $\begin{array}{l}\text { Successful } \\
\text { aging* } \\
n=721\end{array}$ & $\begin{array}{l}\text { Normal } \\
\text { aging } \\
n=1855\end{array}$ & $\begin{array}{l}\text { Fatal or nonfatal } \\
\text { CVD event } \\
n=321\end{array}$ & $\begin{array}{c}\text { Non-CVD } \\
\text { death } \\
n=147\end{array}$ & \\
\hline Age, yr & $57.1 \pm 5.2$ & $56.1 \pm 5.0$ & $56.9 \pm 5.1$ & $59.6 \pm 5.2$ & $59.5 \pm 5.3$ & 0.001 \\
\hline Sex, female & $818(26.9)$ & $180(25.0)$ & $533(28.7)$ & $59(18.4)$ & $46(31.3)$ & 0.006 \\
\hline \multicolumn{7}{|l|}{ Socioeconomic status } \\
\hline Low & $371(12.2)$ & $41(5.7)$ & $266(14.3)$ & $38(11.8)$ & $26(17.7)$ & $<0.001$ \\
\hline Intermediate & $1275(41.9)$ & $269(37.3)$ & $807(43.5)$ & $140(43.6)$ & $59(40.1)$ & \\
\hline High & $1398(45.9)$ & $411(57.0)$ & $782(42.2)$ & $143(44.5)$ & $62(42.2)$ & \\
\hline \multicolumn{7}{|l|}{ Smoking status } \\
\hline Never & $1580(51.9)$ & $409(56.7)$ & $957(51.6)$ & $152(47.4)$ & $62(42.2)$ & $<0.001$ \\
\hline Former & $1213(39.8)$ & $276(38.3)$ & 739 (39.8) & $139(43.3)$ & $59(40.1)$ & \\
\hline Current & $251 \quad(8.2)$ & $36 \quad(5.0)$ & $159(8.6)$ & $30 \quad(9.3)$ & $26(17.7)$ & \\
\hline \multicolumn{7}{|l|}{ Physical activity } \\
\hline Inactive & $852(28.0)$ & $167(23.2)$ & $547(29.5)$ & $88(27.4)$ & $50(34.0)$ & 0.007 \\
\hline Moderately active & $519(17.0)$ & $122(16.9)$ & $322(17.4)$ & $47(14.6)$ & $28(19.0)$ & \\
\hline Active & $1673(55.0)$ & $432(59.9)$ & $986(53.2)$ & $186(57.9)$ & $69(46.9)$ & \\
\hline Use of anti-inflammatory drugs & $295 \quad(9.7)$ & $37 \quad(5.1)$ & $193(10.4)$ & $41(12.8)$ & $24(16.3)$ & $<0.001$ \\
\hline Acute inflammation & $86(2.8)$ & $9(1.2)$ & $60 \quad(3.2)$ & $13(4.0)$ & $4(2.7)$ & 0.02 \\
\hline Obesity $¥$ & $361(11.9)$ & $46 \quad(6.4)$ & $249(13.4)$ & $40(12.5)$ & $26(17.7)$ & $<0.001$ \\
\hline Use of lipid-lowering drugsł & 75 (2.5) & $15(2.1)$ & $46 \quad(2.5)$ & $11(3.4)$ & $3(2.0)$ & 0.4 \\
\hline \multicolumn{7}{|l|}{ Interleukin-6 level§ at baseline } \\
\hline Low & $756(24.8)$ & $257(35.6)$ & $431(23.2)$ & $49(15.3)$ & $19(12.9)$ & $<0.001$ \\
\hline Intermediate & $1456(47.8)$ & $344(47.7)$ & $896(48.3)$ & $158(49.2)$ & $58(39.5)$ & \\
\hline High & $832(27.3)$ & $120(16.6)$ & $528(28.5)$ & $114(35.5)$ & $70(47.6)$ & \\
\hline \multicolumn{7}{|c|}{$\begin{array}{l}\text { No. of times interleukin- } 6 \text { level was } \\
\text { high over } 5 \text {-yr exposure periodף }\end{array}$} \\
\hline 0 & $1867(61.3)$ & $526(73.0)$ & $1110(59.8)$ & $164(51.1)$ & $67(45.6)$ & $<0.001$ \\
\hline 1 & $791(26.0)$ & $145(20.1)$ & $507(27.3)$ & $98(30.5)$ & $41(27.9)$ & \\
\hline 2 & $386(12.7)$ & $50(6.9)$ & $238(12.8)$ & $59(18.4)$ & $39(26.5)$ & \\
\hline \multicolumn{7}{|c|}{$\begin{array}{l}\text { Note: } C V D=\text { cardiovascular disease, } S D=\text { standard deviation. } \\
\text { *Free of major chronic disease and with optimal physical, mental and cognitive functioning. } \\
\text { tFor comparisons among the } 4 \text { outcome groups; } \chi^{2} \text { test for categorical variables and Student } t \text { test for age. } \\
\text { fValues for body mass index were missing for } 373 \text { participants; values for use of lipid-lowering drugs were missing for } 10 \text { participants. } \\
\text { §Low }=\leq 1.0 \mathrm{ng} / \mathrm{L} \text {, intermediate }=1.1-2.0 \mathrm{ng} / \mathrm{L}, \text { high }=>2.0 \mathrm{ng} / \mathrm{L} \text {. } \\
\text { ПInterleukin- } 6 \text { was measured twice }(5 \mathrm{yr} \text { before baseline and at baseline); } 0=\text { neither measurement was high, } 1=\text { either measurement was high, } 2=\text { both } \\
\text { measurements were high. }\end{array}$} \\
\hline
\end{tabular}


olds for interleukin-6; therefore, these thresholds are the ones used previously in the Whitehall II study. ${ }^{18}$ The number of times each participant had a high interleukin-6 level over the 5-year exposure period $(0,1$ or 2 times) was the measure used to assess chronic inflammation. ${ }^{18}$

We used logistic regression models to assess the association between interleukin- 6 levels (at baseline and over the 5-year exposure period) and each aging phenotype. Each phenotype was coded as a dichotomous variable: successful aging (v. normal aging, cardiovascular and noncardiovascular death phenotypes combined), fatal and nonfatal cardiovascular disease events (v. successful and normal aging phenotypes combined) and noncardiovascular death (v. successful and normal aging phenotypes combined). Analyses were first adjusted for sex and age and further adjusted for socioeconomic status, health behaviours, acute inflammation and use of anti-inflammatory drugs. These analyses were repeated using C-reactive protein levels as the marker of inflammation. Further logistic regression models were performed specifically to examine the association between interleukin6 levels and each component of successful aging (good cardiovascular, respiratory, musculoskeletal and cognitive functioning, good mental well-being, and absence of diabetes, cancer and disability). This analysis was restricted to participants in the normal or successful aging phenotypes.
As reported in Appendix 3 (available at www .cmaj.ca/lookup/suppl/doi:10.1503/cmaj.122072 /-/DC1), we ran several sensitivity analyses to examine potential competing risk bias and the effect of sample selection and missing data on the associations. We used net reclassification improvement statistics to test the extent to which assessing the level of interleukin-6 twice, as compared with a single measurement, provided a stronger predictor of future aging phenotypes. ${ }^{19,20}$

All analyses were conducted using the SAS version 9 (SAS Institute).

\section{Results}

Of the 3044 participants included in our study, $721(23.7 \%)$ met the criteria for successful aging at the 10-year follow-up, $321(10.6 \%)$ had cardiovascular disease events (42 fatal and 279 nonfatal), and 147 (4.8\%) died from noncardiovascular causes. The remaining 1855 (60.9\%) were included in the normal aging phenotype. Characteristics of the participants were compared across these 4 aging phenotypes (Table 1). Compared with the normal aging group, participants in the successful aging group were more likely to have low interleukin-6 levels at baseline, whereas those who had a cardiovascular disease event or died from noncardiovascular causes were more likely to have high interleukin-6 levels.

Interleukin-6 levels at baseline and over the 5year exposure period were significantly associ-

Table 2: Sex- and age-adjusted association between interleukin-6 levels at baseline and over the 5-year exposure period and aging phenotypes at 10-year follow-up*

\begin{tabular}{|c|c|c|c|c|c|c|}
\hline \multirow[b]{2}{*}{ Variable } & \multicolumn{2}{|c|}{$\begin{array}{l}\text { Successful agingt } \\
\qquad n=721\end{array}$} & \multicolumn{2}{|c|}{$\begin{array}{l}\text { Fatal or nonfatal CVD event } \\
\qquad n=321\end{array}$} & \multicolumn{2}{|c|}{$\begin{array}{c}\text { Non-CVD death } \\
n=147\end{array}$} \\
\hline & $\begin{array}{l}\text { No. of } \\
\text { patients }\end{array}$ & OR $(95 \% \mathrm{Cl})$ & $\begin{array}{l}\text { No. of } \\
\text { patients }\end{array}$ & OR $(95 \% \mathrm{Cl})$ & $\begin{array}{l}\text { No. of } \\
\text { patients }\end{array}$ & OR $(95 \% \mathrm{Cl})$ \\
\hline \multicolumn{7}{|c|}{ Interleukin-6 level‡ at baseline } \\
\hline Low (ref) & 257 & 1.00 & 49 & 1.00 & 19 & 1.00 \\
\hline Intermediate & 344 & $0.64(0.53-0.78)$ & 158 & $1.47(1.04-2.06)$ & 58 & $1.39(0.81-2.36)$ \\
\hline High & 120 & $0.36(0.28-0.46)$ & 114 & $1.97(1.37-2.82)$ & 70 & $3.06(1.80-5.18)$ \\
\hline \multicolumn{7}{|c|}{$\begin{array}{l}\text { No. of times interleukin- } 6 \text { level was } \\
\text { high over } 5 \text {-yr exposure period§ }\end{array}$} \\
\hline 0 (ref) & 526 & 1.00 & 164 & 1.00 & 67 & 1.00 \\
\hline 1 & 145 & $0.58(0.47-0.72)$ & 98 & $1.47(1.12-1.93)$ & 41 & $1.48(0.99-2.21)$ \\
\hline 2 & 50 & $0.42(0.31-0.58)$ & 59 & $1.54(1.30-2.35)$ & 39 & $2.75(1.80-4.20)$ \\
\hline \multicolumn{7}{|c|}{$\begin{array}{l}\text { Note: } \mathrm{Cl}=\text { confidence interval, } \mathrm{CVD}=\text { cardiovascular disease, } \mathrm{OR}=\text { odds ratio, ref }=\text { reference group. } \\
\text { *Age- and sex-adjusted logistic regression assessed associations of inflammation with } 3 \text { outcomes: successful aging }(\mathrm{v} \text {. normal aging, CVD event and non-CVD } \\
\text { death phenotypes combined), total } n=3044 ; \text { fatal or nonfatal CVD event ( } \mathrm{v} \text {. successful and normal aging phenotypes combined), total } n=2897 \text { (excludes } 147 \\
\text { participants who had a non-CVD death); and non-CVD death ( } \mathrm{v} \text {. successful and normal aging phenotypes combined), total } n=2723 \text { (excludes } 321 \text { participants who } \\
\text { had CVD event). } \\
\text { tFree of major chronic disease and with optimal physical, mental and cognitive functioning. } \\
\text { fLow }=\leq 1.0 \mathrm{ng} / \mathrm{L} \text {, intermediate }=1.1-2.0 \mathrm{ng} / \mathrm{L} \text {, high }=>2.0 \mathrm{ng} / \mathrm{L} \text {. } \\
\text { SInterleukin-6 was measured twice }(5 \mathrm{yr} \text { before baseline and at baseline); } 0=\text { neither measurement was high, } 1=\text { either measurement was high, } 2=\text { both } \\
\text { measurements were high. }\end{array}$} \\
\hline
\end{tabular}


ated with aging phenotypes at the 10-year follow-up in the sex- and age-adjusted analyses (Table 2). After further adjustment for potential confounders, participants with a high interleukin-6 level at baseline were significantly less likely than those with a low interleukin-6 level to achieve successful aging (odds ratio [OR] 0.45, $95 \%$ confidence interval $[\mathrm{CI}] 0.35-0.59)$ and were at increased risk of a cardiovascular disease event (OR 1.76, 95\% CI 1.21-2.55) or death from a noncardiovascular cause (OR 2.64, 95\% CI 1.53-4.55) over the 10-year follow-up period (Figure 2). Participants who had a high interleukin-6 level once or twice over the 5-year exposure period were less likely to achieve successful aging than those who never had a high

\section{A: IL-6 level at baseline}

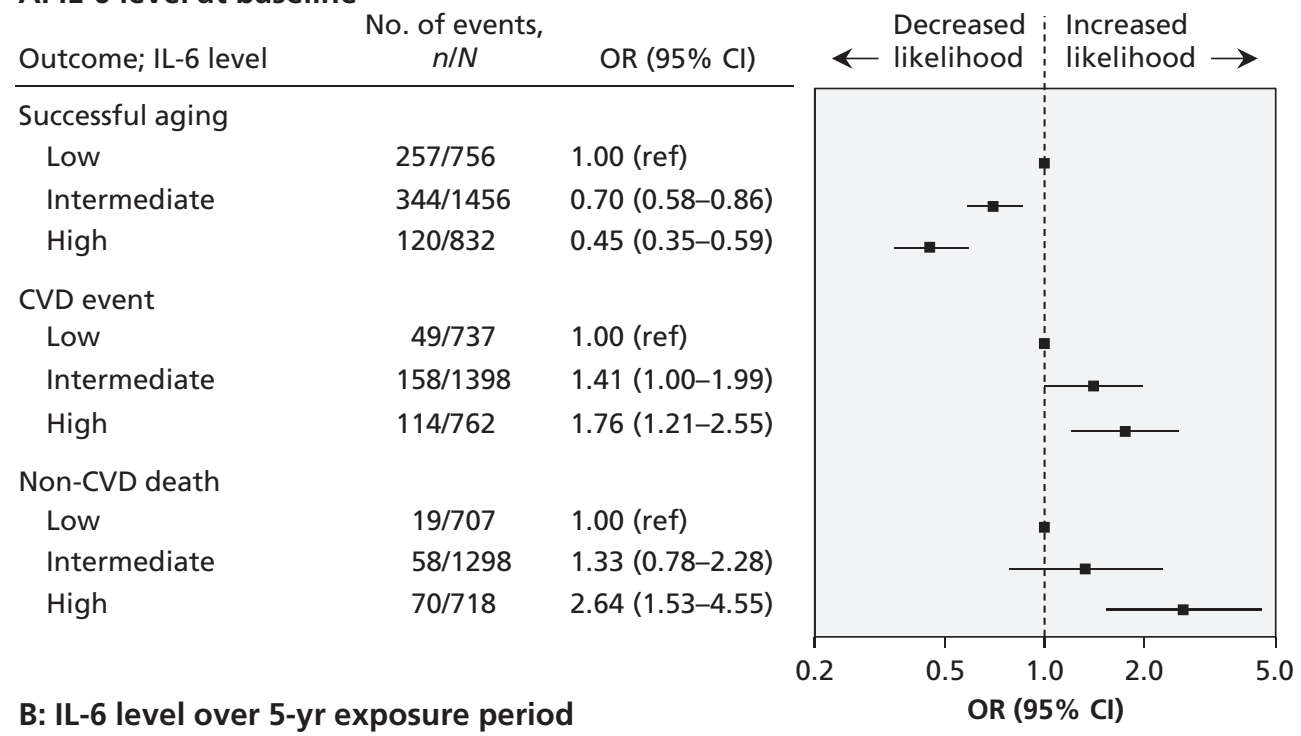

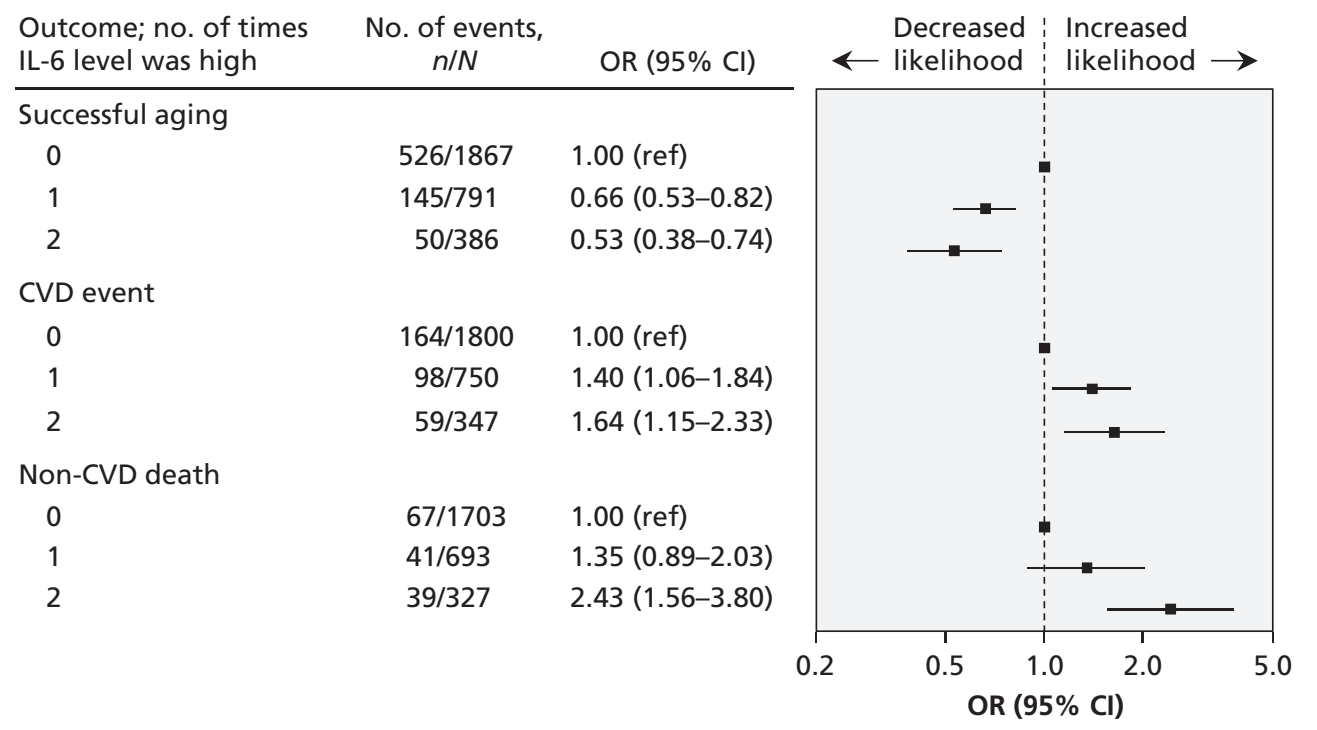

Figure 2: Multivariable logistic regression of associations between interleukin-6 (IL-6) levels at baseline (A) and over a 5-year exposure period (B) and subsequent aging phenotypes at 10-year follow-up. Aging phenotypes were: successful aging (v. normal aging, cardiovascular disease [CVD] event and non-CVD death phenotypes combined), total $n=3044$; CVD event ( $v$. successful and normal aging phenotypes combined), total $n=2897$ (excludes 147 participants who died of non-CVD causes); and non-CVD death (v. successful and normal aging phenotypes combined), total $n=2723$ (excludes 321 participants who had fatal or nonfatal CVD event). For model A, IL- 6 levels were separated into 3 categories: low $(\leq 1.0 \mathrm{ng} / \mathrm{L})$, intermediate (1.1-2.0 ng/L) and high (> $2.0 \mathrm{ng} / \mathrm{L})$. For model B, IL-6 was measured twice (5 yr before baseline and at baseline); 0 = neither measurement was high, 1 = either measurement was high, 2 = both measurements were high. Odds ratios (ORs) were adjusted for sex, age, socioeconomic status, smoking status, physical activity, acute inflammation and use of anti-inflammatory drugs; values greater than 1.0 indicate an increased likelihood of the outcome. $\mathrm{Cl}=$ confidence interval, ref = reference group. 
level during the exposure period (OR for having a high level once 0.66 , 95\% CI $0.53-0.82$; OR for having a high level twice $0.53,95 \%$ CI 0.38 $0.74 ; p_{\text {trend }}<0.001$ ) (Figure 2). Having a high interleukin-6 level twice over the 5-year exposure period was also associated with an increased risk of cardiovascular disease (OR 1.64, 95\% CI 1.15-2.33; $\left.p_{\text {trend }}=0.002\right)$ and death from a noncardiovascular cause (OR 2.43, 95\% CI $\left.1.56-3.80 ; p_{\text {trend }}<0.001\right)$. When we replaced interleukin- 6 by $\mathrm{C}$-reactive protein in the regression model, we observed similar significant associations with aging phenotypes (Appendix 4, available at www.cmaj.ca/lookup/suppl/doi:10 .1503/cmaj.122072/-/DC1).

When we examined the individual components of successful aging, we found that high interleukin-6 levels at baseline were associated with lower odds of good cardiovascular, respiratory and musculoskeletal functioning and good mental well-being, as well as lower odds of remaining free of diabetes and disability (Table 3). When inflammation was assessed over the 5-year exposure period, we observed that having a high interleukin-6 level twice over the exposure period was associated with lower odds of good respiratory and musculoskeletal functioning and lower odds of remaining free of diabetes (Table 3).
Repeated analyses with multinomial regression to examine potential competing risk bias gave findings similar to those in the main analysis, which suggested that competing risk bias was unlikely (Appendix 5, available at www.cmaj.ca /lookup/suppl/doi:10.1503/cmaj.122072/-/DC1). In further sensitivity analyses, the results did not materially change after we excluded obese participants (body mass index $\geq 30$ ), those taking antiinflammatory medications or those with acute inflammation (C-reactive protein $>10 \mathrm{mg} / \mathrm{L}$ ) (Appendix 6, available at www.cmaj.ca/lookup /suppl/doi:10.1503/cmaj.122072/-/DC1). The OR for the association between inflammation and noncardiovascular death among the 5353 participants with complete data on inflammation and cause of death was largely similar to the OR among the 3044 participants included in the main analyses. Furthermore, when we used multiple imputation to deal with missing data on inflammation and covariates, we noted associations similar to those reported in the main analyses. Finally, the net reclassification improvement calculations showed that information from 2 measurements of inflammation improved the risk prediction for successful aging by $23.6 \%$, for cardiovascular events by $15.4 \%$ and for noncardiovascular death by $22.1 \%$ (Appendix 7, avail-

Table 3: Association between interleukin-6 levels at baseline and over the 5-year exposure period and individual components of successful aging* at 10-year follow-up among 2576 participants $\dagger$

\begin{tabular}{|c|c|c|c|c|c|c|c|c|}
\hline \multirow[b]{2}{*}{ Variable } & \multicolumn{8}{|c|}{ Component of successful aging; adjusted OR $(95 \% \mathrm{Cl})$} \\
\hline & $\begin{array}{c}\text { Good } \\
\text { cardiovascular } \\
\text { functioning }\end{array}$ & $\begin{array}{c}\text { Absence of } \\
\text { diabetes }\end{array}$ & $\begin{array}{c}\text { Good } \\
\text { respiratory } \\
\text { functioning }\end{array}$ & $\begin{array}{c}\text { Good } \\
\text { musculoskeletal } \\
\text { functioning }\end{array}$ & $\begin{array}{c}\text { Good } \\
\text { cognitive } \\
\text { functioning }\end{array}$ & $\begin{array}{c}\text { Good } \\
\text { mental } \\
\text { well-being }\end{array}$ & $\begin{array}{l}\text { Absence of } \\
\text { cancer }\end{array}$ & $\begin{array}{l}\text { Absence of } \\
\text { disability }\end{array}$ \\
\hline \multicolumn{9}{|c|}{ IL-6 level§ at baseline } \\
\hline Low (ref) & 1.00 & 1.00 & 1.00 & 1.00 & 1.00 & 1.00 & 1.00 & 1.00 \\
\hline Intermediate & $\begin{array}{c}0.93 \\
(0.73-1.19)\end{array}$ & $\begin{array}{c}0.52 \\
(0.37-0.75)\end{array}$ & $\begin{array}{c}0.80 \\
(0.60-1.07)\end{array}$ & $\begin{array}{c}0.77 \\
(0.59-1.00)\end{array}$ & $\begin{array}{c}1.03 \\
(0.79-1.36)\end{array}$ & $\begin{array}{c}0.71 \\
(0.49-1.04)\end{array}$ & $\begin{array}{c}0.62 \\
(0.44-0.89)\end{array}$ & $\begin{array}{c}0.71 \\
(0.53-0.96)\end{array}$ \\
\hline High & $\begin{array}{c}0.74 \\
(0.56-0.98)\end{array}$ & $\begin{array}{c}0.35 \\
(0.24-0.51)\end{array}$ & $\begin{array}{c}0.53 \\
(0.39-0.72)\end{array}$ & $\begin{array}{c}0.62 \\
(0.45-0.83)\end{array}$ & $\begin{array}{c}0.93 \\
(0.68-1.28)\end{array}$ & $\begin{array}{c}0.56 \\
(0.37-0.86)\end{array}$ & $\begin{array}{c}0.79 \\
(0.52-1.20)\end{array}$ & $\begin{array}{c}0.62 \\
(0.44-0.86)\end{array}$ \\
\hline$p_{\text {trend }}$ value & 0.04 & $<0.001$ & $<0.001$ & 0.001 & 0.7 & 0.01 & 0.3 & $<0.001$ \\
\hline \multicolumn{9}{|c|}{$\begin{array}{l}\text { No. of times IL-6 level } \\
\text { was high over } 5-y r \\
\text { exposure period } \emptyset\end{array}$} \\
\hline 0 (ref) & 1.00 & 1.00 & 1.00 & 1.00 & 1.00 & 1.00 & 1.00 & 1.00 \\
\hline 1 & $\begin{array}{c}0.72 \\
(0.58-0.90)\end{array}$ & $\begin{array}{c}0.66 \\
(0.51-0.87)\end{array}$ & $\begin{array}{c}0.71 \\
(0.55-0.92)\end{array}$ & $\begin{array}{c}0.86 \\
(0.68-1.09)\end{array}$ & $\begin{array}{c}0.79 \\
(0.62-1.01)\end{array}$ & $\begin{array}{c}0.80 \\
(0.58-1.11)\end{array}$ & $\begin{array}{c}1.15 \\
(0.83-1.59)\end{array}$ & $\begin{array}{c}0.89 \\
(0.69-1.15)\end{array}$ \\
\hline 2 & $\begin{array}{c}0.76 \\
(0.55-1.06)\end{array}$ & $\begin{array}{c}0.44 \\
(0.31-0.62)\end{array}$ & $\begin{array}{c}0.41 \\
(0.30-0.58)\end{array}$ & $\begin{array}{c}0.67 \\
(0.49-0.93)\end{array}$ & $\begin{array}{c}0.79 \\
(0.56-1.12)\end{array}$ & $\begin{array}{c}0.71 \\
(0.46-1.09)\end{array}$ & $\begin{array}{c}0.82 \\
(0.54-1.23)\end{array}$ & $\begin{array}{c}0.80 \\
(0.57-1.13)\end{array}$ \\
\hline$p_{\text {trend }}$ value & 0.01 & $<0.001$ & $<0.001$ & 0.02 & 0.06 & 0.07 & 0.7 & $<0.001$ \\
\hline \multicolumn{9}{|c|}{$\begin{array}{l}\text { Note: } \mathrm{Cl}=\text { confidence interval, } \mathrm{OR}=\text { odds ratio. } \\
\text { *Free of major chronic disease and with optimal physical, mental and cognitive functioning. } \\
\text { †Participants who had a fatal or nonfatal cardiovascular disease (CVD) event and those who died from a non-CVD cause }(n=468) \text { were excluded from these analyses. } \\
\text { ¥Adjusted for sex, age, socioeconomic status, smoking status, physical activity, acute inflammation and use of anti-inflammatory drugs. } \\
\text { \$Low }=\leq 1.0 \mathrm{ng} / \mathrm{L} \text {, intermediate }=1.1-2.0 \mathrm{ng} / \mathrm{L} \text {, high }=>2.0 \mathrm{ng} / \mathrm{L} \text {. } \\
\text { १llnterleukin- } 6 \text { was measured twice }(5 \mathrm{yr} \text { before baseline and at baseline); } 0=\text { neither measurement was high, } 1=\text { either measurement was high, } 2=\text { both } \\
\text { measurements were high. }\end{array}$} \\
\hline
\end{tabular}


able at www.cmaj.ca/lookup/suppl/doi:10.1503 /cmaj.122072/-/DC1).

\section{Interpretation}

We showed that having chronically high levels of interleukin-6 halved the odds of successful aging 10 years later and was associated with increased odds of future cardiovascular disease and death from noncardiovascular causes in a dose-response fashion. These associations were independent of socioeconomic factors, health behaviours (smoking, physical activity), conditions such as obesity, acute inflammation and the use of antiinflammatory drugs.

Most previous studies investigated the impact of inflammation on cardiovascular and mortality outcomes based on only a single measurement of inflammation. ${ }^{4} \mathrm{~A}$ recent collaborative metaanalysis suggested that prolonged increases in interleukin-6 levels were associated with an increased risk of coronary artery disease.$^{10} \mathrm{In}$ that report, the long-term average impact of interleukin- 6 was estimated from a single measure of the inflammatory marker using a "regression dilution ratio" method. Our use of repeated measures of interleukin- 6 confirmed this finding.

Three studies reported on an association between change in interleukin- 6 levels and agerelated health outcomes. Two studies, involving $860^{21}$ and $736^{22}$ older adults, showed that shortterm (3-yr) and long-term (9-yr) increases in interleukin- 6 were associated with an increased 3-year risk of overall mortality. A further study based on the Cardiovascular Health Study All Stars study $(n=840)^{23}$ showed that the 9-year increase in interleukin- 6 was also associated with an increased risk of cardiovascular disease. Our results on the associations between inflammation, cardiovascular events and death from noncardiovascular causes are concordant with those reported in the literature. However, our results also show that measuring chronic inflammation twice may be a better predictor of future cardiovascular disease and noncardiovascular death than measuring inflammation only once.

We found that chronic inflammation characterized by a high interleukin-6 level (> $2.0 \mathrm{ng} / \mathrm{L}$ ) measured twice over the 5-year exposure period nearly halved the odds of successful aging after 10 years of follow-up compared with maintaining a low level of interleukin- $6(<1.0 \mathrm{ng} / \mathrm{L}$ twice over the exposure period). Our study showed that high interleukin-6 levels at baseline were inversely associated with most of the individual components that characterize successful aging: good cardiovascular, respiratory and musculoskeletal functioning, good mental well-being, and the absence of diabetes and disability. Exceptions were components related to good cognitive function and the absence of cancer. Regarding cognition, a more robust association with inflammation was expected according to the available epidemiologic literature, which supported an association between inflammation and cognitive decline. ${ }^{5}$ In contrast, the nonsignificant association between inflammation and cancer reported in our study is in accordance with the results of the British Women's Heart and Health Study. ${ }^{24}$ It showed that, in a cohort of 4286 women aged 60-79 years, elevated interleukin-6 concentrations were similarly associated with an increased risk of death among older women with and without cancer, which suggested that these inflammatory markers were indicators of nonmalignant comorbidities rather than cancer itself..$^{24}$

Our results also suggest that maintaining a low interleukin-6 level may facilitate successful aging by reducing the likelihood of impaired respiratory and musculoskeletal functioning and increasing the likelihood of remaining free of diabetes.

\section{Limitations}

This study has some important limitations. First, because our study cohort was comprised exclusively of middle-aged, London-based civil servants at baseline, findings may have limited generalizability. ${ }^{15}$

Second, we restricted analyses to participants who had complete data on aging outcomes and inflammatory markers, which constituted only $53 \%$ of the 5706 participants at baseline (Figure 1). However, comparable results observed in supplementary analyses - one in which we included all participants for whom mortality records were available, and the other in which we used multiple imputation methods to deal with missing data suggest that a major bias due to sample selection was unlikely an explanation for our results.

Third, we used 2 measurements of interleukin-6 over the 5-year exposure period to assess long-term inflammation. Although we showed that the ability to predict aging phenotypes was significantly better when inflammation was assessed twice rather than once, having a high interleukin-6 level at the beginning and end of a 5-year exposure period should not necessarily be regarded as an indicator of chronic inflammation, because repeated short-term inflammatory responses are possible.

Finally, common to other observational studies and despite adjustment for sociodemographic and health behaviour factors, we cannot exclude the possibility that the observed associations between inflammation and aging phenotypes may be explained in part by residual confounding. 


\section{Conclusion}

By analyzing aging phenotypes based on validated clinic-based measures and medical records in a large sample with a long follow-up, we were able to show that chronic inflammation, as ascertained by repeat measurements of interleukin-6, was related to a range of unhealthy aging phenotypes and a decreased likelihood of successful aging. Maintaining a low interleukin-6 level may facilitate successful aging by reducing the likelihood of impaired respiratory and musculoskeletal functioning and increasing the likelihood of remaining free of diabetes. If confirmed, these results shed new light on the importance of assessing long-term chronic inflammation in geriatric clinical practice, not only to target individuals at risk of unhealthy aging but also to promote ideal health by managing long-term chronic inflammation.

\section{References}

1. Singh $\mathrm{T}$, Newman $\mathrm{AB}$. Inflammatory markers in population studies of aging. Ageing Res Rev 2011;10:319-29.

2. Pradhan AD, Manson JE, Rifai N et al. C-reactive protein, interleukin 6 , and risk of developing type 2 diabetes mellitus. JAMA 2001;286:327-34.

3. Wellen J, Helmer KG, Grigg P et al. Spatial characterization of $\mathrm{T} 1$ and $\mathrm{T} 2$ relaxation times and the water apparent diffusion coefficient in rabbit Achilles tendon subjected to tensile loading. Magn Reson Med 2005;53:535-44.

4. Emerging Risk Factors Collaboration, Kaptoge S, Di Angelantonio E, et al. C-reactive protein concentration and risk of coronary heart disease, stroke, and mortality: an individual participant meta-analysis. Lancet 2010;375:132-40.

5. Gorelick PB Role of inflammation in cognitive impairment: results of observational epidemiological studies and clinical trials. Ann N Y Acad Sci 2010;1207:155-62.

6. Satizabal CL, Zhu YC, Mazoyer B et al. Circulating IL-6 and CRP are associated with MRI findings in the elderly: the 3CDijon Study. Neurology 2012;78:720-7.

7. Medzhitov R. Inflammation 2010: new adventures of an old flame. Cell 2010;140:771-6.

8. Hotamisligil GS. Inflammation and metabolic disorders. Nature 2006;444:860-7.

9. IL6R Genetics Consortium Emerging Risk Factors Collaboration, Sarwar N, Butterworth AS, et al. Interleukin-6 receptor pathways in coronary heart disease: a collaborative metaanalysis of 82 studies. Lancet 2012;379:1205-13.

10. Danesh J, Kaptoge S, Mann AG et al. Long-term interleukin-6 levels and subsequent risk of coronary heart disease: two new prospective studies and a systematic review. PLoS Med 2008;5:e78.

11. Patterson CC, Smith AE, Yarnell JW et al. The associations of interleukin-6 (IL-6) and downstream inflammatory markers with risk of cardiovascular disease: the Caerphilly Study. Atherosclerosis 2010;209:551-7.

12. Barbieri M, Ferrucci L, Ragno E et al. Chronic inflammation and the effect of IGF-I on muscle strength and power in older persons. Am J Physiol Endocrinol Metab 2003;284:E481-7.

13. Perry VH, Newman TA, Cunningham C. The impact of systemic infection on the progression of neurodegenerative disease. Nat Rev Neurosci 2003;4:103-12.

14. Interleukin-6 Receptor Mendelian Randomisation Analysis (IL6R MR) Consortium. The interleukin-6 receptor as a target for prevention of coronary heart disease: a mendelian randomisation analysis. Lancet 2012;379:1214-24.

15. Marmot M, Brunner E. Cohort profile: the Whitehall II study. Int J Epidemiol 2005;34:251-6.

16. Gimeno D, Brunner EJ, Lowe GD et al. Adult socioeconomic position, C-reactive protein and interleukin-6 in the Whitehall II prospective study. Eur J Epidemiol 2007;22:675-83.

17. Akbaraly, T, Sabia S, Hagger-Johnson G et al., Does overall diet in midlife predict future aging phenotypes? A cohort study. Am J Med 2013;126:411-9.

18. Kivimäki M, Shipley MJ, Batty GD et al. Long-term inflammation increases risk of common mental disorder: a cohort study. Mol Psychiatry 2013 Apr. 9 [Epub ahead of print].

19. Pencina MJ, D’Agostino RB Sr, D'Agostino RB Jr et al. Evaluat- ing the added predictive ability of a new marker: from area under the ROC curve to reclassification and beyond. Stat Med 2008; 27:157-72.

20. Pencina MJ, D'Agostino RB Sr, Steyerberg EW. Extensions of net reclassification improvement calculations to measure usefulness of new biomarkers. Stat Med 2011;30:11-21.

21. Kizer JR, Arnold AM, Jenny NS et al. Longitudinal changes in adiponectin and inflammatory markers and relation to survival in the oldest old: the Cardiovascular Health Study All Stars study. J Gerontol A Biol Sci Med Sci 2011;66:1100-7.

22. Alley DE, Crimmins E, Bandeen-Roche K et al. Three-year change in inflammatory markers in elderly people and mortality: the Invecchiare in Chianti study. J Am Geriatr Soc 2007;55:1801-7.

23. Jenny NS, French B, Arnold AM et al. Long-term assessment of inflammation and healthy aging in late life: the Cardiovascular Health Study All Stars. J Gerontol A Biol Sci Med Sci 2012;67: 970-6.

24. Heikkilä K, Ebrahim S, Rumley A et al. Associations of circulating $\mathrm{C}$-reactive protein and interleukin-6 with survival in women with and without cancer: findings from the British Women's Heart and Health Study. Cancer Epidemiol Biomarkers Prev 2007;16:1155-9.

Affiliations: Institut National de la Santé et de la Recherche Médicale (Akbaraly), Hôpital La Colombière, Montpellier, France; Department of Epidemiology and Public Health (Hamer, Hagger-Johnson, Shipley, Kivimäki), University College London, London, UK; School of Social and Community Medicine (Ferrie), University of Bristol, Bristol, UK; Institute of Cardiovascular and Medical Sciences (Lowe), University of Glasgow, Glasgow, UK; Centre for Cognitive Ageing and Cognitive Epidemiology (Batty), University of Edinburgh, Edinburgh, UK; and Institut National de la Santé et de la Recherche Médicale (Singh-Manoux), Assistance Publique-Hôpitaux de Paris, Paris, France

Contributors: Tasnime Akbaraly contributed to the conception and design of the study, conducted the statistical analyses, interpreted the data, wrote the manuscript and is the guarantor of the analyses. Mark Hamer, Jane Ferrie, David Batty, Gareth Hagger-Johnson and Archana Singh-Manoux contributed to the conception and design of the study and the acquisition of data and revised the manuscript for important intellectual content. Gordon Lowe contributed to the acquisition of data and revised the manuscript for important intellectual content. Martin Shipley contributed to conception and design of study, the acquisition of data and the statistical analyses and revised the manuscript for important intellectual content. Mika Kivimäki contributed to the conception and design of study, and the acquisition, analysis and interpretation of the data, revised the manuscript for important intellectual content and is the guarantor of the study. All of the authors approved the final version of the manuscript submitted for publication.

Funding: The Whitehall II study is supported by grants from the British Medical Research Council (MRC grant no. K013351), the British Heart Foundation, the British Health and Safety Executive, the British Department of Health, the US National Heart, Lung, and Blood Institute (grant no. R01HL036310), the US National Institute on Aging (grant nos. R01AG013196 and R01AG034454) and the US Agency for Health Care Policy and Research (grant no. HS06516).

Tasnime Akbaraly is supported by the LanguedocRoussillon Region (Chercheur d'avenir Grant 2011). Mika Kivimäki is supported by the MRC, the Academy of Finland and a professorial fellowship from the Economic and Social Research Council.

The study sponsors had no role in the design of the study, the collection, analysis or interpretation of the data, the writing of the report or the decision to submit the article for publication.

Acknowledgements: The authors thank all of the participating civil service departments and their welfare personnel and establishment officers; the Occupational Health and Safety Agency; the Council of Civil Service Unions; all of the civil servants who participated in the Whitehall II study; and all of the members of the Whitehall II study team, which comprises research scientists, statisticians, study coordinators, nurses, data managers, administrative assistants and data entry staff, who make the study possible. 